\title{
PELAKSANAAN PROGRAM SUNSET POLICY DALAM PENYAJIAN LAPORAN KEUANGAN PERUSAHAAN
}

\author{
Neneng Nurias \\ Staf Keuangan PT Molindo Raya Industrial \\ Jl. Raya Sumber Waras No. 255 Lawang \\ email: nenengcay $@$ yahoo.com
}

Abstract

Research by title sunset policy implementation in the company's financial statement presentation. One of the government's efforts to improve our economy is relying on tax revenue, associated with these two new tax policies applied are better known as the Sunset Policy. Sunset Policy is a policy of tax facilities in the form of administrative sanction taxation of interest on taxes not paid or less regulated in pasal 37A UU KUP(Undang-Undang Nomor 28 Tahun 2007). There are two types of sunset policy under the terms of which are: Sunset Policy For New Taxpayer and Sunset Policy For Taxpayer Older. So this is a problem in research whether there is influence sunset policy program for the company's financial statement presentation. Data analysis technique used is qualitative analysis by comparing the tax before sunset policy and after sunset policy. The data presented in the form of figures, calculations and descriptive explanation that describes what is in the company, the more qualitative analysis of the problem. Based on these results it can be concluded that the presence of a sunset policy program undertaken by the government, many taxpayers who voluntarily report the amount of income tax to be paid correctly but many taxpayers who are concerned over the financial statements that have been reported to the Tax office, so that they consciously includes in the report that have been made so that they are free from administrative penalties and fines.

Keywords: sunset policy, financial statements 


\begin{abstract}
Abstrak
Penelitian dengan judul pelaksanaan program sunset policy dalam penyajian laporan keuangan perusahaan. Salah satu usaha pemerintah untuk meningkatkan perekonomian kita adalah mengandalkan penerimaan dari pajak, berkaitan dengan hal tersebut maka diterapkan kebijakan baru dalam perpajakan yang lebih dikenal dengan istilah Sunset Policy. Sunset Policy adalah kebijakan pemberian fasilitas perpajakan dalam bentuk penghapusan sanksi administrasi perpajakan berupa bunga atas pajak yang tidak atau kurang dibayarkan yang diatur dalam Pasal 37A Undang-Undang KUP (Undang-Undang Nomor 28 Tahun 2007). Ada dua jenis sunset policy berdasarkan ketentuan yaitu: Sunset Policy Untuk Wajib Pajak Baru dan Sunset Policy Untuk Wajib Pajak Lama. Maka permasalahan dalam peneliyian ini adalah apakah ada pengaruh program sunset policy terhadap penyajian laporan keuangan perusahaan. Tekhnik analisa data yang digunakan yaitu analisa kualitatif dengan membandingkan pajak sebelum sunset policy dan sesudah sunset policy. Data-data yang di sajikan dalam bentuk angka-angka, perhitungan dan penjelasannya secara deskriptif yang menggambarkan apa yang ada dalam perusahaan, maka analisa permasalahan lebih bersifat kualitatif. Berdasarkan hasil penelitian ini dapat disimpulkan bahwa dengan adanya program sunset policy yang dilakukan oleh pemerintah, maka banyak wajib pajak yang secara sukarela melaporkan besarnya pajak penghasilan yang harus dibayarkan secara benar namun banyak juga wajib pajak yang merasa khawatir atas laporan keuangan yang telah dilaporkan kepada Kantor Pajak, sehingga mereka secara sadar melakukan pembetulan atas laporan yang telah dibuat sehingga mereka terbebas dari sanksi maupun denda administrasi.
\end{abstract}

Kata kunci: sunset policy, laporan keuangan

\title{
PENDAHULUAN
}

Salah satu usaha pemerintah untuk meningkatkan perekonomian kita adalah mengandakan penerimaan dari sektor pajak yang diterima oleh Negara. Dan sebagai wujud untuk meningkatkan hal tersebut pemerintah berupaya untuk melakukan program ekstensifikasi dan intensifikasi. Ekstensifikasi lebih menekankan pada program meningkatkan jumlah wajib pajak terdaftar, sedangkan intensifikasi mengacu pada perluasan objek pajak yang dapat dikenakan pajak misalnya intensifikasi objek pajak sektor tertentu seperti konstruksi, properti, bubur kertas, perkebunan kelapa sawit dan sebagainya (www.direktorat jenderal pajak.go.id).

Untuk memenuhi APBN 2007 dan meningkatkan pendapatan atas pajak ke kas negara, maka diberlakukanlah sebuah kebijakan baru dalam perpajakan yang lebih dikenal dengan istilah Sunset Policy. Dimana dalam kebijakan tersebut mengatur tentang adanya pengampunan pajak kepada wajib pajak tertentu. UndangUndang KUP Tahun 2008 memberikan wewenang kepada Direktorat Jenderal 
Pajak untuk menghimpun data perpajakan dan mewajibkan instansi pemerintah, lembaga, asosiasi dan pihak lainnya untuk memberikan data kepada Direktorat Jenderal Pajak. Sunset Policy adalah program penghapusan sanksi administrasi pajak penghasilan. Sunset Policy merupakan fasilitas perpajakan yang diatur berdasarkan Pasal 37A UU No.28 Tahun 2007 tentang Ketentuan Umum dan Tata Cara Perpajakan.

Ketentuan ini memungkinkan Direktorat Jenderal Pajak mengetahui ketidakbenaran pemenuhan kewajiban perpajakan yang telah dilaksanakan oleh masyarakat. Wajib pajak yang dapat menikmati fasilitas kebijakan sunset policy adalah pertama, wajib pajak orang pribadi yang secara sukarela mendaftarkan diri untuk memperoleh NPWP dalam tahun 2008 dan menyampaikan SPT Tahunan wajib pajak orang pribadi untuk tahun 2007 dan sebelumnya diberikan penghapusan sanksi administrasi berupa bunga atas pajak yang tidak atau kurang dibayar. Kedua, wajib pajak yang dalam tahun 2008 menyampaikan pembetulan SPT Tahunan PPh wajib pajak orang pribadi sebelum tahun pajak 2007 atau SPT Tahunan PPh wajib pajak badan sebelum tahun pajak 2007 yang mengakibatkan pajak yang masih harus dibayar menjadi lebih besar, diberikan penghapusan sanksi administrasi berupa bunga atas keterlambatan pelunasan kekurangan pembayaran pajak.

Untuk menghindarkan masyarakat dari pengenaan sanksi perpajakan yang timbul apabila masyarakat tidak melaksanakan kewajiban perpajakannya secara benar, Direktorat Jenderal Pajak di tahun 2008 memberikan kesempatan seluasluasnya kepada masyarakat untuk mulai memenuhi kewajiban perpajakannya. Dengan adanya program sunset policy tersebut banyak wajib pajak yang secara sukarela mendaftarkan diri untuk memperoleh NPWP dan ini tentunya membawa dampak yang cukup signifikan, hal ini disebabkan wajib pajak ingin melaporkan kewajiban pepajakan yang harus dibayarkan.

Sesuai dengan UU RI No.28 Tahun 2007 tentang Perubahan Ketiga atas UU RI No. 6 Tahun 1983 tentang Ketentuan Umum dan Tata Cara Perpajakan, terdapat pasal yang disisipkan antara Pasal 37 dan Pasal 38, yaitu Pasal 37A ayat (1) yang berbunyi sebagai berikut:

"Wajib Pajak yang menyampaikan pembetulan Surat Pemberitahuan Tahunan Pajak Penghasilan sebelum Tahun Pajak 2007, yang mengakibatkan pajak yang masih harus dibayar menjadi lebih besar dan dilakukan paling lama dalam jangka waktu 1 (satu) tahun setelah berlakunya UndangUndang ini, dapat diberikan pengurangan atau penghapusan sanksi administrasi berupa bunga atas keterlambatan pelunasan kekurangan pembayaran pajak yang ketentuannya diatur dengan atau berdasarkan Peraturan Menteri Keuangan."

Pengampunan pajak berlaku untuk wajib pajak yang secara sukarela melakukan pembetulan Surat Pemberitahuan Tahunan (SPT) Pajak sebelum tahun 2007, 
sehingga secara tidak langsung jika ada ketidakbenaran dalam pelaporan SPT, laporan keuangan wajib pajak juga harus diadakan pembetulan.

\section{Rumusan Masalah}

Berdasarkan latar belakang tersebut maka masalah yang dirumuskan oleh penulis adalah bagaimana pengaruh pelaksanaan program sunset policy dalam hubungannya dengan penyajian laporan keuangan perusahaan?

\section{TINJAUAN PUSTAKA}

\section{Sunset Policy}

\section{Pengertian Sunset Policy}

Sunset Policy adalah kebijakan pemberian fasilitas perpajakan dalam bentuk penghapusan sanksi administrasi perpajakan berupa bunga atas pajak yang tidak atau kurang dibayarkan yang diatur dalam Pasal 37A Undang-Undang Ketentuan Umum dan Tata Cara Perpajakan (Undang-Undang Nomor 28 Tahun 2007).

\section{Dasar Hukum Sunset Policy}

Sunset Policy merupakan pelaksanaan dari Pasal 37A Undang-Undang No.28 Tahun 2007 tentang Perpajakan, yaitu:

1) Wajib Pajak yang membetulkan SPT Tahunan sebelum tahun pajak 2007 selama masa 1 (satu) tahun setelah diberlakukannya Undang-Undang ini, diberikan pengurangan atau penghapusan sanksi administrasi.

2) Wajib Pajak Orang Pribadi yang dengan sukarela mendaftarkan diri untuk memperoleh NPWP paling lama 1 (satu) tahun setelah Undang-Undang ini, diberi kemudahan:

a) Penghapusan sanksi administrasi,

b) Tidak dilakukan pemeriksaan pajak kecuali terdapat data yang menyatakan bahwa SPT Wajib Pajak tidak benar.

\section{Subjek Sunset Policy}

Subjek Sunset Policy dalam hal ini adalah siapa saja yang dapat memanfaatkan program Sunset Policy, yaitu:

1) Orang Pribadi yang belum memiliki Nomor Pokok Wajib Pajak (NPWP), yang dalam tahun 2008 secara sukarela mendaftarkan diri untuk memperoleh NPWP dan menyampaikan SPT Tahunan PPh untuk tahun pajak 2007 dan tahuntahun pajak sebelumnya paling lambat 31 Maret 2009.

2) Wajib Pajak Orang Pribadi dan Badan yang telah memiliki NPWP sebelum tahun 2008, yang menyampaikan pembetulan SPT Tahunan PPh Tahun Pajak 
2006 dan tahun-tahun pajak sebelumnya untuk melaporkan penghasilan yang belum diperhitungkan dalam pelaporan SPT Tahunan PPh yang telah disampaikan.

\section{Objek Sunset Policy}

Berbeda dengan pajak penghasilan yang objek pajaknya adalah penghasilan di mana pengertian penghasilan merupakan setiap tambahan kemampuan ekonomis yang diterima atau diperoleh wajib pajak, baik yang berasal dari Indonesia maupun dari luar Indonesia, yang dapat dipakai untuk konsumsi atau menambah kekayaan Wajib Pajak yang bersangkutan, dengan nama dan bentuk apapun.

Objek Sunset Policy adalah pajak-pajak yang tidak atau kurang dibayar. Pajak kurang dibayar tersebut timbul karena adanya pembetulan SPT tahun-tahun sebelumnya oleh Wajib Pajak baik Orang Pribadi atau Badan.

\section{Tujuan Sunset Policy}

Direktorat Jenderal Pajak mengadakan program Sunset Policy dengan tujuan meningkatkan kesadaran Wajib Pajak untuk mendaftarkan diri dan mendapatkan Nomor Pokok Wajib Pajak (NPWP). Selain itu Sunset Policy juga sebagai pemicu tambahan penerimaan negara untuk merealisasikan APBN 2007.

\section{Pajak}

\section{Pengertian Pajak}

Menurut Valentina (2003:3) pajak merupakan salah satu kemandirian suatu bangsa dalam pembiayaan pembangunan yang menggali potensi dalam negeri.

Inti dari pengertian tersebut adalah bahwa pajak:

1. dipungut dari semua rakyat yang menurut undang-undang wajib membayar pajak.

2. dimaksudkan untuk mengisi kas Negara.

3. dapat dipaksakan dalam membayarnya karena diatur oleh undang-undang.

4. tidak mendapatkan balas jasa secara langsung pada saat rakyat membayar pajak kepada Negara, tetapi

5. digunakan untuk pengeluaran umum, artinya tidak terbatas pada sebagian orang saja tetapi menyeluruh untuk seluruh rakyat baik yang sudah membayar pajak maupun tidak.

\section{Fungsi Pajak}

Pajak merupakan iuran rakyat yang berfungsi untuk membiayai pengeluaranpengeluaran Negara untuk kepentingan umum. Namun demikian, fungsi pajak dapat dibedakan menjadi dua yaitu: 
1. Fungsi pendanaan (budgetair)

2. Fungsi mengatur (regulair)

\section{Kedudukan Hukum Pajak}

Pemungutan pajak diatur dalam Pasal 23 ayat (2) UUD'45: pengenaan dan pemungutan pajak untuk keperluan Negara berdasarkan undang-undang. Artinya pajak merupakan peralihan kekayaan masyarakat kepada pemerintah. Selanjutnya keseluruhan peraturan-peraturan yang meliputi kewenangan pemerintah untuk mengambil kekayaan seseorang dan menyerahkan kembali kepada masyarakat melalu kas Negara termsuk dalam ruang lingkup hukum pajak. Pengaturan ini menyangkut hubungan hukum antara Negara dengan orang pribadi/ badan yang mempunyai kewajiban membayar pajak.

\section{Ketentuan Umum dan Tatacara Perpajakan}

Dalam pembahasan Ketentuan Umum dan Tatacara Perpajakan akan dijumpai istilah-istilah yaitu:

a. Wajib Pajak adalah orang pribadi atau badan yang menurut ketentuan peraturan perundang-undangan perpajakan ditentukan untuk melaukan kewajiban perpajakan, termasuk pemungut pajak atau pemotong pajak tertentu

b. Badan adalah sekumpulan orang dan atau model yang merupakan kesatuan baik yang melakukan usaha maupun yang tidak melakukan usaha yang meliputi perseroan terbatas, persekutuan komanditer, perseroan lainnya, badan usaha milik Negara atau daerah dengan nama dan dalam bentuk apapun, firma, kongsi, koperasi, dana pension, pesekutuan, perkumpulan, yayasan, organisasi masa, organisasi social politik atau organisasi yang sejenis, lembaga, bentu usaha tetap dan bentuk badan lainnya.

c. Pengusaha adalah orang pribadi atau badan dalam bentuk apapun yang dalam kegiatan usaha atau pekerjaannya menghasilkan barang, mengimpor barang, mengekspor barang atau melakukan usaha diluar daerah pabean, melakukan usaha jasa, atau memanfaatkan jasa dari luar daerah pabean.

d. Pengusaha Kena Pajak adlah pengusaha sebagaimana

e. Masa pajak adalah jangka waktu yang lamanya sama dengan 1(satu) bulan takwim atau jangka waktu lain yang ditetapkan dengan Keputusan Menteri Keuangan paling lama 3(tiga) bulam takwim.

f. Tahun pajak adalah jangka waktu 1(satu) tahu takwim kecuali bila wajib pajak menggunakan tahun buku yang tidak sama dengan tahun takwim.

g. Bagian Tahun Pajak, bagian dari jangka waktu satu tahun pajak.

h. Pajak yang terutang, pajak yang harus dibayar pada suatu saat, dalam Masa Pajak, Tahun Pajak, atau dalam bagian Tahun Pajak menurut ketentuan peraturan perundang-undangan perpajakan. 
i. Surat Pemberitahuan adalah surat yang oleh wajib pajak digunakan untuk melaporkan penghitungan atau pembayaran pajak, objek pajak dan atau bukan objek pajak dan atau harta dan kewajiban, menurut ketentuan peraturan perundang-undangan perpajakan.

j. Surat Pemberitahuan Masa adalah surat pemberitahuan atas pajak untuk suatu Masa Pajak atau sama dengan satu bulan takwim.

k. Surat Pemberitahuan Tahunan adalah surat pemberitahuan atas pajak untuk suatu Tahun Pajak atau Bagian Tahun Pajak.

1. Surat Setoran Pajak adalah surat yang oleh wajib pajak digunakan untuk melakukan pembayaran atau penyetoran pajak yang terutang ke kas negara melalui kantor pos dan bank badan usaha milik negara atau bank badan usaha milik daerah atau tempat pembayaran lain yang ditunjuk oleh Menteri Keuangan.

m. Surat Ketetapan Pajak adalah surat ketetapan yang meliputi Surat Ketetapan Pajak Kurang Bayar atau Surat Ketetapan Lebih Bayar atau Surat Ketetapan Pajak Nihil.

n. Surat Tagihan Pajak adalah surat untuk melakukan tagihan pajak dan atau sanksi administrasi berupa bunga dan atau denda.

o. Surat Keputusan Pembetulan adalah surat keputusan yang membetulkan kesalahan tulis, hitung dan atau kekeliruan penerapan ketentuan dalam peraturan perundang-undangan perpajakan yang terdapat dalam surat ketetapan pajak, surat tagian pajak, surat keputusan keberatan, surat keputusan pengurangan atau penghapusan sanksi administrasi, surat keputusan pengurangan atau pembatalan ketetapan pajak yang tidak benar, atau surat keputusan pengembalian pendahuluan kelebihan pajak.

\section{Pengertian Laporan Keuangan}

Menurut Zaki (2004:17), ’Laporan keuangan merupakan ringkasan dari suatu proses pencatatan, merupakan suatu ringkasan dari transaksi-transaksi keuangan yang terjadi selama tahun buku yang bersangkutan".

Sesuai dengan Standar Akuntansi Keuangan per September 2007 pada Kerangka Dasar Penyusunan dan Penyajian Laporan Keuangan (par.7, baris 5355 dan 1-6) menyebutkan bahwa "Laporan keuangan merupakan bagian dari proses pelaporan keuangan. Laporan keuangan yang lengkap biasanya meliputi neraca, laporan laba rugi, laporan perubahan posisi keuangan (yang dapat disajikan dalam berbagai cara misalnya, sebagai laporan arus kas, atau laporan arus dana), catatan dan laporan lain serta materi penjelasan yang merupakan bagian integral dari laporan keuangan. Di samping itu juga termasuk skedul dan informasi tambahan yang berkaitan dengan laporan tersebut, misalnya, informasi keuangan segmen industri dan geografis serta pengungkapan pengaruh perubahan harga." 


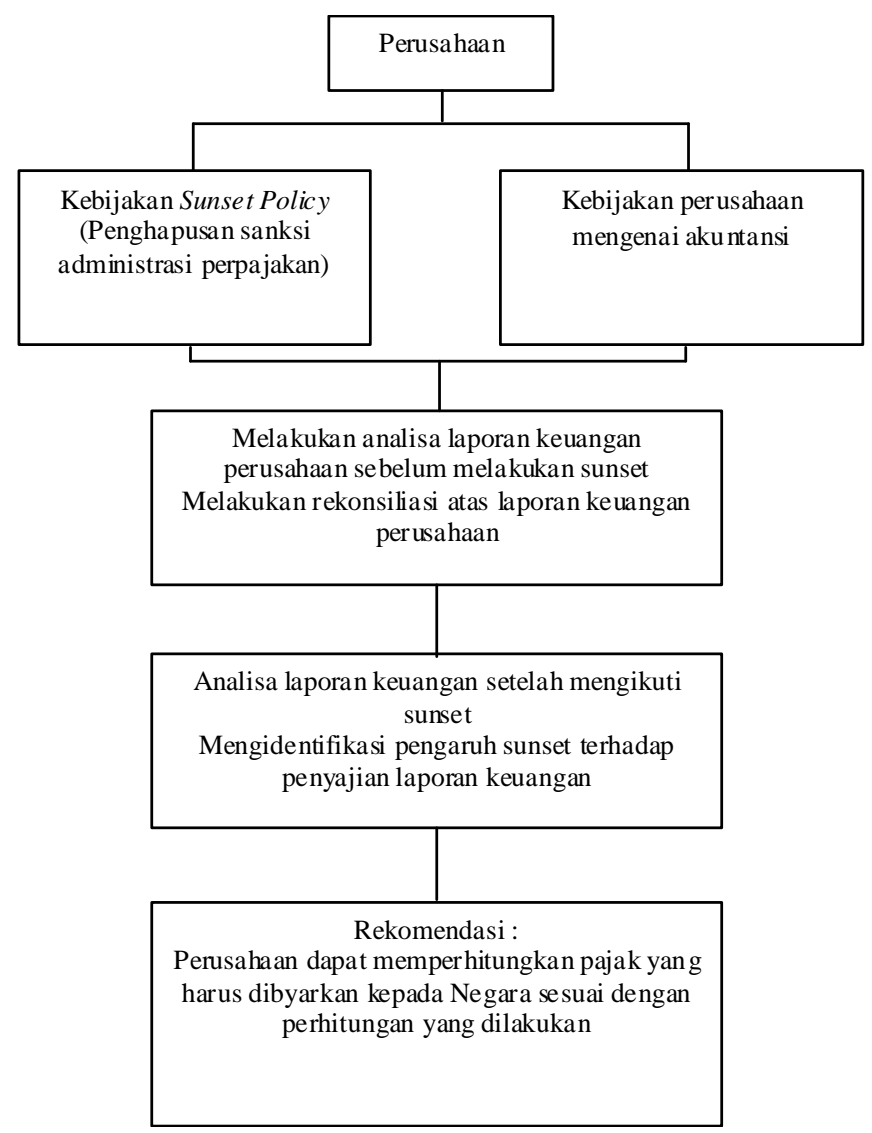

Gambar 1. Kerangka Konseptual

\section{HASIL DAN PEMBAHASAAN}

\section{Data Perusahaan}

Laporan keuangan perusahaan PR. Putra Jaya terdiri dari Laporan Keuangan Neraca, Laporan Keuangan Laba Rugi, Laporan Perubahan Ekuitas, Laporan Arus Kas dan Catatan Atas Laporan Keuangan. Namun pada penelitian ini penulis hanya akan membahas tentang Laporan Keuangan Laba Rugi, karena hal ini sangat berkaitan dengan besarnya pajak penghasilan yang harus dibayarkan oleh perusahaan kepada pihak pemerintah. Berikut ini penulis akan menyajikan laporan laba rugi perusahaan PR. Putra Jaya pada tahun 2006 dan tahun 2007 pada tabel 1. 
Tabel 1. PR. Putra Jaya

Laporan Laba Rugi Tahun 2006 dan Tahun 2007

(dalam rupiah)

\begin{tabular}{lcc}
\hline \multicolumn{1}{c}{ Keterangan } & Tahun 2006 & Tahun 2007 \\
\hline Penjualan & $5,680,445,000$ & $6,152,500,000$ \\
Beban Pokok Penjualan & $(5,361,299,687)$ & $(5,742,808,443)$ \\
\multicolumn{1}{c}{ Laba Kotor } & $\mathbf{3 1 9 , 1 4 5 , 3 1 3}$ & $\mathbf{4 0 9 , 6 9 1 , 5 5 7}$ \\
Beban Usaha: & & \\
Beban Penjualan & $(21,288,954)$ & $(19,127,900)$ \\
Beban Umum dan Administrasi & $(241,408,337)$ & $(239,755,046)$ \\
Jumlah Beban Usaha & $(\mathbf{2 6 2 , 6 9 7 , 2 9 1 )}$ & $(\mathbf{2 5 8 , 8 8 2 , 9 4 6 )}$ \\
Laba Usaha & $\mathbf{5 6 , 4 4 8 , 0 2 2}$ & $\mathbf{1 5 0 , 8 0 8 , 6 1 1}$ \\
& & \\
Pendapatan dan Beban Lain-lain & & \\
Pendapatan Jasa Giro & - & $3,453,774$ \\
Beban Lain-lain & - & $(85,185,573)$ \\
Jumlah Pendapatan dan Beban Lain & $\mathbf{( 8 1 , 7 3 1 , 7 9 9 )}$ \\
Laba (Rugi) Sebelum Pajak & & \\
Taksiran Pajak Penghasilan & & $\mathbf{6 9 , 0 7 6 , 8 1 2}$ \\
Laba (Rugi) Setelah Pajak & $\mathbf{5 6 , 4 4 8 , 0 2 2}$ & $\mathbf{( 4 , 0 9 3 , 8 6 0 )}$ \\
\hline
\end{tabular}

(Sumber Data :PR. Putra Jaya, diolah)

Pada tabel 1 merupakan laporan keuangan laba rugi perusahaan pada tahun 2006 dan 2007 hal ini dilakukan sebagai pembanding laba rugi perusahaan selama dua tahun. Laporan laba rugi yang disajikan pada tahun 2006 merupakan laporan perusahaan sebelum mengikuti program sunset policy. Pada tahun 2006 penjualan yang diperoleh perusahaan sebesar 5.680.445.000 sedangkan pada tahun 2007 penjualan adalah sebesar 6.152.500.000, hal ini menunjukkan kenaikan nilai penjualan sebesar 472.055.000 (8,32\%). Kenaikan nilai penjualan ini juga diikuti dengan meningkatnya beban pokok produksinya yaitu pada tahun 2006 beban pokok produksi sebesar 5.361.299.687 sedangkan pada tahun 2007 beban pokok produksinya sebesar 5.742.808.443. Beban pokok produksi mengalami kenaikan sebesar $381.508 .756(7,12 \%)$. Berdasarkan tabel tersebut dapat diketahui besarnya laba kotor perusahan pada tahun 2006 adalah sebesar 319.145.313 sedangkan pada tahun 2007 laba kotor perusahaan sebesar 409.691.557. Hal ini dapat kita lihat bahwa ada kenaikan laba kotor sebesar 90.546.244 (28,37\%). 
262.697.291, jumlah beban usaha tersebut terdiri dari beban pemasaran sebesar 21.288.954, beban gaji karyawan sebesar 127.360.000, beban listrik sebesar 9.756.035, beban telepon sebesar 11.309.790, beban administrasi kantor sebesar 10.835.324, beban pemeliharaan kendaraan sebesar 3.225.000, beban pemeliharaan bangunan 3.250.000, beban pemeliharaan peralatan sebesar 8.553 .750 , beban transportasi sebesar 18.000.625, beban penyusutan sebesar 46.617.813, dan sumbangan sebesar 2.500.000.

Pada tabel 1 tersebut kita dapat mengetahui laba usaha perusahaan pada tahun 2006 sebesar 56.448.022, nilai ini diperoleh dari laba kotor dikurangi dengan beban usaha pada tahun berjalan. Sedangkan pada tahun 2007 besarnya 150.808.611. Dimana laba usaha tersebut mengalami kenaikan sebesar $94.360 .589(167,16 \%)$. Pada tahun 2006 perusahan tidak memiliki pendapatan dan beban lain-lain sedangkan pada tahun 2007 terdapat pendapatan lain-lain yaitu pendapatan bunga sebesar 3.453.774 dan beban lain-lain sebesar 85.185.573.

Laba bersih perusahaan sebelum pajak pada tahun 2006 adalah sebesar 56.448.022 dan tahun 2007 sebesar 69.076.812. sedangkan laba bersih perusahaan setelah pajak pada tahun 2006 adalah sebesar 53.603.219, dan pada tahun 2007 sebesar 64.982.952 Besarnya pajak penghasilan yang harus dibayarkan oleh perusahaan pada tahun 2006 adalah sebesar 2.844.802 sedangkan pada tahun 2007 pajak yang harus dibayarkan adalah sebesar 4.093.860.

\section{Rekonsiliasi Laporan Keuangan}

Pada tabel 1 tersebut akan dilakukan rekonsiliasi atas laporan keuangan perusahaan, hal ini dikarenakan adanya koreksi atas akun-akun laporan keuangan tersebut. Adapun proses rekonsiliasi atas laporan keuangan perusahaan dapat dilihat pada tabel 2 . 


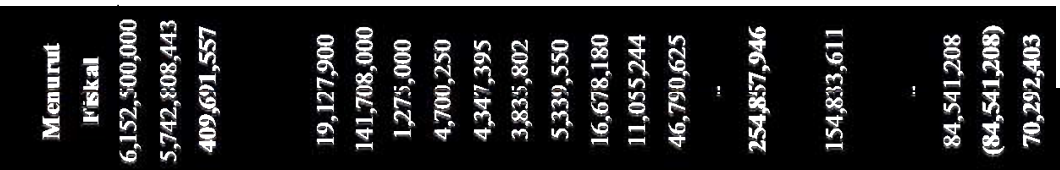
1

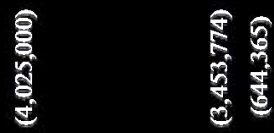

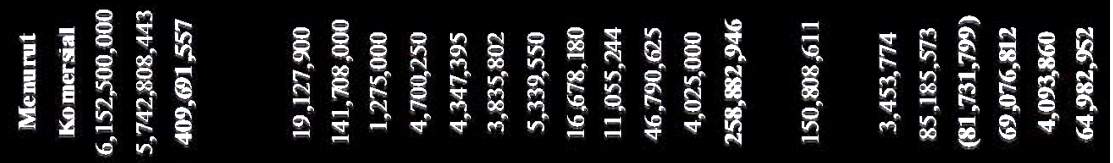

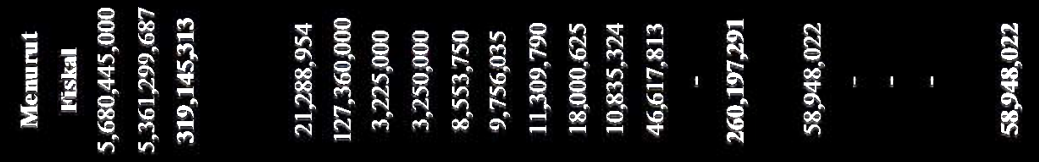

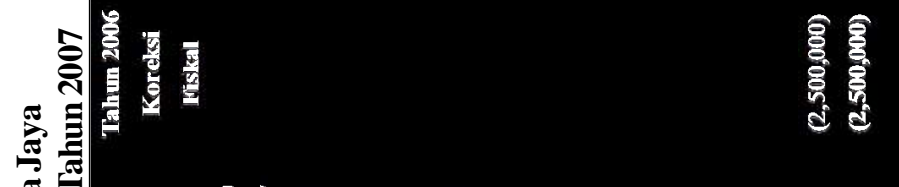
焉焉

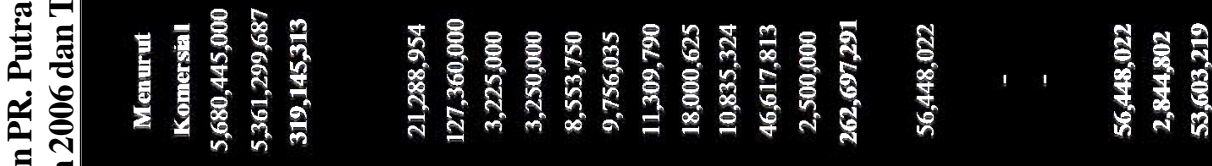
F 焉 约 뜨

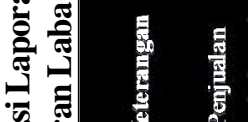

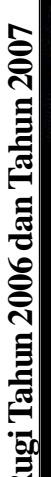

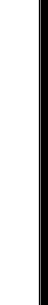


Pada tabel 2 tersebut merupakan rekonsiliasi atas laporan keuangan laba rugi perusahaan. Di mana pada tabel tersebut dapat kita ketahui bahwa pada tahun 2006 terdapat koreksi fiskal positif atas sumbangan sebesar 2.500.000. Sumbangan yang dikeluarkan oleh perusahaan menurut fiskal tidak dapat dikurangkan dari penghasilan kena pajak karena sumbangan tersebut bukan untuk kepentingan perusahaan sehingga harus dikeluarkan dari laporan laba rugi perusahaan. Sedangkan pada tahun 2007 juga terdapat koreksi positif atas sumbangan sebesar 4.025.000 dan beban lain-lain sebesar 644.365 serta koreksi fiskal negatif atas pendapatan bunga sebesar 3.453.774.

Berdasarkan tabel 1 tersebut maka kita dapat menghitung besarnya pajak penghasilan sesuai dengan Undang-Undang Perpajakan no.17 tahun 2000 yaitu sebagai berikut:

Tabel 3. PR. Putra Jaya Perhitungan Taksiran Pajak Penghasilan Untuk periode

\begin{tabular}{lcc}
\multicolumn{1}{c}{ Ket erangan } & (dalam rupiah) \\
\hline Laba Bersih Sebelum Pajak & Tahun 2006 & Tahun 2007 \\
Penghasilan Tidak Kena Pajak & $58,948,022$ & $70,292,403$ \\
Penghasilan Kena Pajak & $18,000,000$ & $18,000,000$ \\
\multicolumn{1}{c}{ Pajak Terutang } & $40,948,022$ & $52,292,403$ \\
$5 \%$ X 25.000.000 = & & \\
$10 \%$ X 15.948.022 = & $1,250,000$ & $1,250,000$ \\
$10 \%$ X 25.000.000 = & $1,594,802$ & \\
$15 \%$ X 2.292.403 = & - & $2,500,000$ \\
Total Pajak Terutang & - & $\mathbf{4 , 0 9 3 , 8 6 0}$ \\
\hline
\end{tabular}

(Sumber data: PR. Putra Jaya, diolah)

Pada tabel 3 dapat kita ketahui besarnya pajak penghasilan yang harus dibayarkan oleh pihak perusahaan pada tahun 2006 dan tahun 2007. Pada tahun 2006 besarnya pajak penghasilan adalah 2.844.802 dan pada tahun 2007 adalah sebesar 4.093.860. Dari data tersebut dapat kita lihat bahwa terjadi peningkatan atas besarnya pajak yang dibayarkan perusahaan yaitu sebesar 1.249.058.

\section{Analisa Data dengan Sunset Policy}

Pemerintah pada tahun 2008 mengeluarkan kebijakan atas peraturan perpajakan yang disebut dengan istilah Sunset Policy di mana dengan adanya program ini 
pemerintah memberikan kebebasan kepada para wajib pajak untuk menghitung dan melaporkan sendiri atas kewajiban perpajakannya. Dengan adanya program ini, pada laporan keuangan perusahaan akan ada beberapa akun yang mengalami perubahan dari segi jumlah. Adapun laporan keuangan laba rugi perusahaan setelah adanya sunset policy adalah sebagai berikut:

Tabel 4. Laporan Laba Rugi Tahun 2006 Setelah Sunset Policy

\begin{tabular}{lc} 
& (dalam rupiah) \\
\hline Keterangan & Tahun 2006 \\
\hline Penjualan & $\mathbf{5 , 6 8 0 , 4 4 5 , 0 0 0}$ \\
Beban Poko k Penjualan & $\mathbf{( 5 , 3 5 1 , 0 8 2 , 4 1 2 )}$ \\
Laba Kotor & $\mathbf{3 2 9 , 3 6 2 , 5 8 8}$ \\
Beban Usaha: & \\
Beban Penjualan & $(21,288,954)$ \\
Beban Umum dan Administrasi & $(241,581,149)$ \\
Jumlah Beban Usaha & $\mathbf{( 2 6 2 , 8 7 0 , 1 0 3 )}$ \\
Laba Usaha & $\mathbf{6 6 , 4 9 2 , 4 8 5}$ \\
Pendapatan dan Beban Lain-lain & \\
Pendapatan Jasa Giro & - \\
Beban Lain-lain & - \\
Jumlah Pendapatan dan Beban Lain & - \\
Laba (Rugi) Sebelum Pajak & $66,492,485$ \\
Taksiran Pajak Penghasilan & $(3,898,872)$ \\
Laba (Rugi) Setelah Pajak & $62,593,613$ \\
\hline
\end{tabular}

(Sumber data: PR. Putra Jaya, diolah)

Berdasarkan tabel 1 dan tabel 4 tersebut kita dapat mengetahui terdapat beberapa akun yang mengalami perubahan yang dikarenakan adanya program sunset policy. Akun yang mengalami perubahan adalah beban pokok penjualan yaitu pada tahun 2006 sebelum sunset beban pokok penjualan sebesar 5.361.299.687 sedangkan setelah adanya sunset beban pokok penjualan adalah sebesar 5.351.082.412. Selain itu akun yang mengalami perubahan adalah beban penyusutan. Berikut ini penulis akan menjabarkan analisa perhitungan perubahan jumlah akun tersebut.

\section{Perlakuan sunset terhadap beban pokok penjualan}

Berikut ini adalah perhitungan beban pokok penjualan sebelum dan sesudah sunset policy pada tabel 5 . 
Tabel 5. Perhitungan Beban Pokok Penjualan PR. Putra Jaya

Laporan Perhitungan Beban Pokok Penjualan

(dalam rupiah)

\begin{tabular}{|c|c|c|}
\hline Keterangan & Sebelum & Sesudah \\
\hline \multicolumn{3}{|l|}{ Bahan Baku: } \\
\hline \multicolumn{3}{|l|}{ Tembakau } \\
\hline Saldo Awal bahan baku tembakau & $252,275,604$ & $252,275,604$ \\
\hline Pembelian bahan baku tembakau & $902,834,095$ & $902,834,095$ \\
\hline Saldo Akhir bahan baku tembakau & $(790,652,840)$ & $(800,984,512)$ \\
\hline Pemakaian Tembakau & $364,456,836$ & $354,125,188$ \\
\hline \multicolumn{3}{|l|}{ Cengkeh } \\
\hline Saldo Awal Cengkeh & - & - \\
\hline Pembelian Cengkeh & $173,000,000$ & $173,000,000$ \\
\hline Saldo Akhir Cengkeh & $(84,246,937)$ & $(84,246,937)$ \\
\hline Pemakaian cengkeh & $88,753,063$ & $88,753,063$ \\
\hline \multicolumn{3}{|l|}{ Saos } \\
\hline Saldo awal saos & - & - \\
\hline Pembelian saos & $15,736,739$ & $15,736,739$ \\
\hline Saldo akhir saos & - & - \\
\hline Pemakaian saos & $15,736,739$ & $15,736,739$ \\
\hline \multicolumn{3}{|l|}{ Alkohol } \\
\hline Saldo awal alkohol & - & - \\
\hline Pembelian alkohol & $25,756,758$ & $25,756,758$ \\
\hline Saldo akhir alkohol & $(15,373,750)$ & $(15,373,750)$ \\
\hline Pemakaian alkohol & $10,383,008$ & $10,383,008$ \\
\hline Pemakaian bahan baku & $479,329,646$ & $468,997,998$ \\
\hline Tenaga kerja langsung & $386,500,000$ & $386,500,000$ \\
\hline \multicolumn{3}{|l|}{ Beban Produksi Tak Langsung } \\
\hline Pemakaian bahan pembantu & $86,270,055$ & $86,270,055$ \\
\hline Poncoan & 296,000 & 296,000 \\
\hline Biaya keperluan pabrik & $4,692,231$ & $4,692,231$ \\
\hline Penyusutan & $19,979,063$ & $20,053,125$ \\
\hline Jumlah Beban Produksi Tidak Langsung & $111,237,348$ & $111,311,411$ \\
\hline Beban Pokok Produksi & $977,066,995$ & $966,809,408$ \\
\hline Saldo Awal Barang Dalam Proses & - & - \\
\hline Saldo Akhir Barang Dalam Proses & - & - \\
\hline Jumlah Biaya Pokok Produksi & $977,066,995$ & $966,809,408$ \\
\hline Pemakaian pita cukai & $4,401,698,784$ & $4,401,698,784$ \\
\hline Jumlah Biaya Produksi Sesudah Dilekati Cukai & $5,378,765,779$ & $5,368,508,192$ \\
\hline Saldo Awal Barang Jadi & $3,686,000$ & $3,686,000$ \\
\hline Saldo Akhir Barang Jadi & $(21,152,091)$ & $(21,111,781)$ \\
\hline Beban Pokok Penjualan & $5,361,299,687$ & $5,351,082,412$ \\
\hline
\end{tabular}

(Sumber data: PR. Putra Jaya, diolah) 
Dari tabel 5 bahan baku yang ada pada perusahaan terutama tembakau mengalami perubahan, perubahan yang terjadi ada pada persediaan akhir dan pemakaian. Data pada saat perusahaan sebelum melakukan sunset nilai persediaan akhir bahan baku tembakau adalah sebesar 790.652.840 dan pemakaiannya adalah sebesar 364.456.836. Sedangkan pada saat telah melakukan sunset data persediaan akhir tembakau sebesar 800.984.512 dan pemakaiannya adalah sebesar 354.125.188. Perubahan nilai persediaan akhir dan pemakaian tembakau ini disebabkan oleh perubahaan jumlah kuantitas pembelian tembakau. Hal ini dikarenakan dilakukan stok opname atas tembakau yang ada. Pada tabel 6 dan tabel 7 dapat dilihat laporan mutasi persediaan tembakau.

Pada tabel 6 dan tabel 7 kita dapat melihat perubahan kuantitas pada pembelian dan saldo akhir tembakau. Perbedaan tersebut dikarenakan telah dilakukan stok opname atas jumlah pembelian tembakau. Selisih yang terjadi pada pembelian tembakau tersebut adalah dikarenakan tembakau memiliki sifat tertentu berkaitan dengan penyimpanannya. Tembakau yang telah dibeli oleh perusahaan tersebut tidak akan langsung digunakan sebagai bahan baku pembuatan rokok, namun oleh perusahaan tembakau tersebut disimpan terlebih dahulu. Pada saat penyimpan tembakau memiliki sifat dan kelembaban tertentu. Sehingga tembakau yang telah melalui proses penimbangan tersebut akan bertambah kuantitasnya.

Perubahan kuantitas pada pembelian tembakau tersebut tentunya akan menyebabkan harga pokok pembelian juga akan mengalami perubahan. Namun secara nilai rupiah tidak akan berubah karena nilai tersebut telah dibayarkan pada periode berjalan. Pemakaian atas tembakau tersebut tidak mengalami perubahan karena jumlah tembakau telah digunakan sesuai dengan produksi yang ada. Selain itu nilai tembakau tersebut telah sesuai dengan perbandingan yang telah ditetapkan untuk industri rokok sesuai dengan nilai cukai yang terpakai.

Perubahan kuantitas pada pembelian akan menimbulkan perubahan pada kuantitas saldo akhir tembakau yang dimiliki perusahaan.

\section{Perlakuan sunset terhadap beban penyusutan}

Pada beban penyusutan yang masuk dalam beban administrasi perusahaan terdapat juga selisih pencatatan yaitu pada tahun 2006 sebelum adanya sunset policy perusahaan mencatat besarnya beban tersebut adalah sebesar 46.617.814 sedangkan setelah adanya sunset besarnya beban penyusutan menjadi 46.790.625. Terdapat selisih pencatatan sebesar 172.813. Pada waktu sebelum adanya sunset perusahaan mencatat besarnya beban penyusutan sebesar 46.617 .814 hal ini akan menyebabkan jumlah beban usaha menjadi lebih kecil sehingga laba perusahaan juga akan turun atau kecil yang mana bila laba perusahaan kecil maka pajak yang harus dibayarkan akan menjadi sedikit juga. Sedangkan pada saat sunset policy perusahaan harus melakukan pembetulan atas kesalahan catat tersebut. Atas 


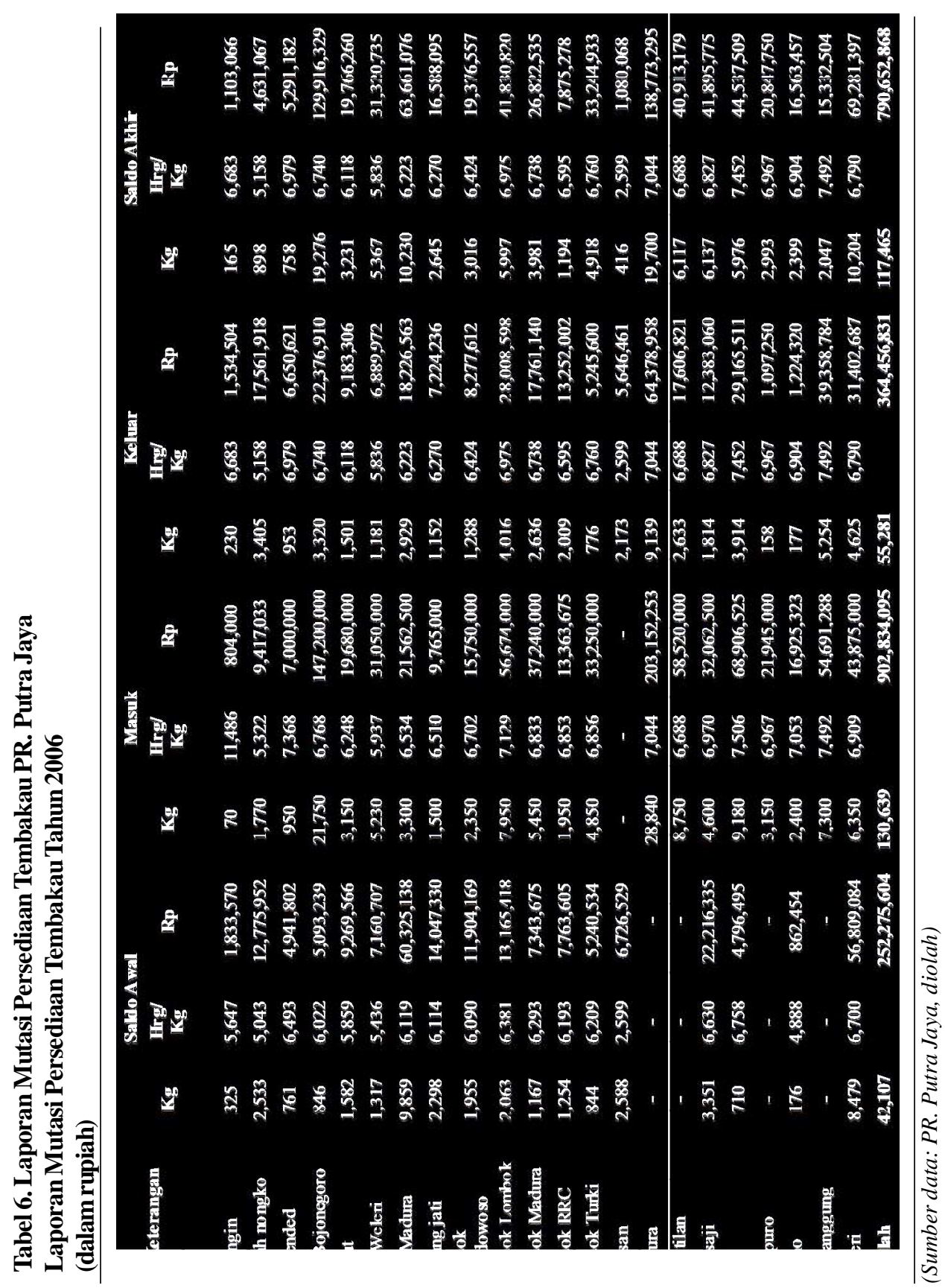




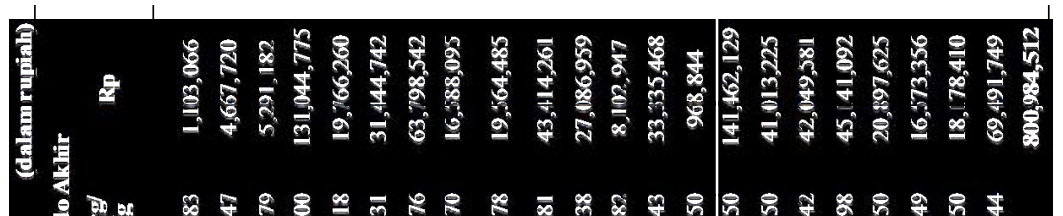

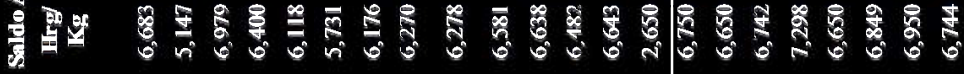

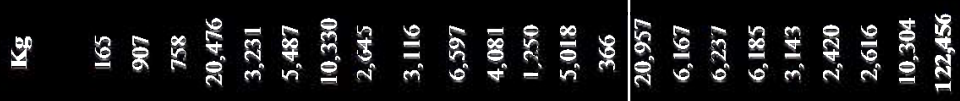

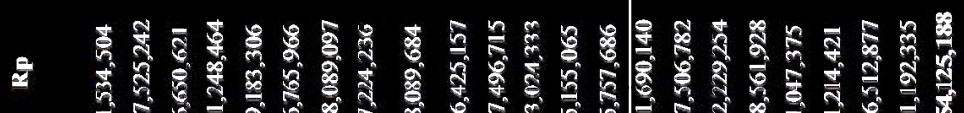

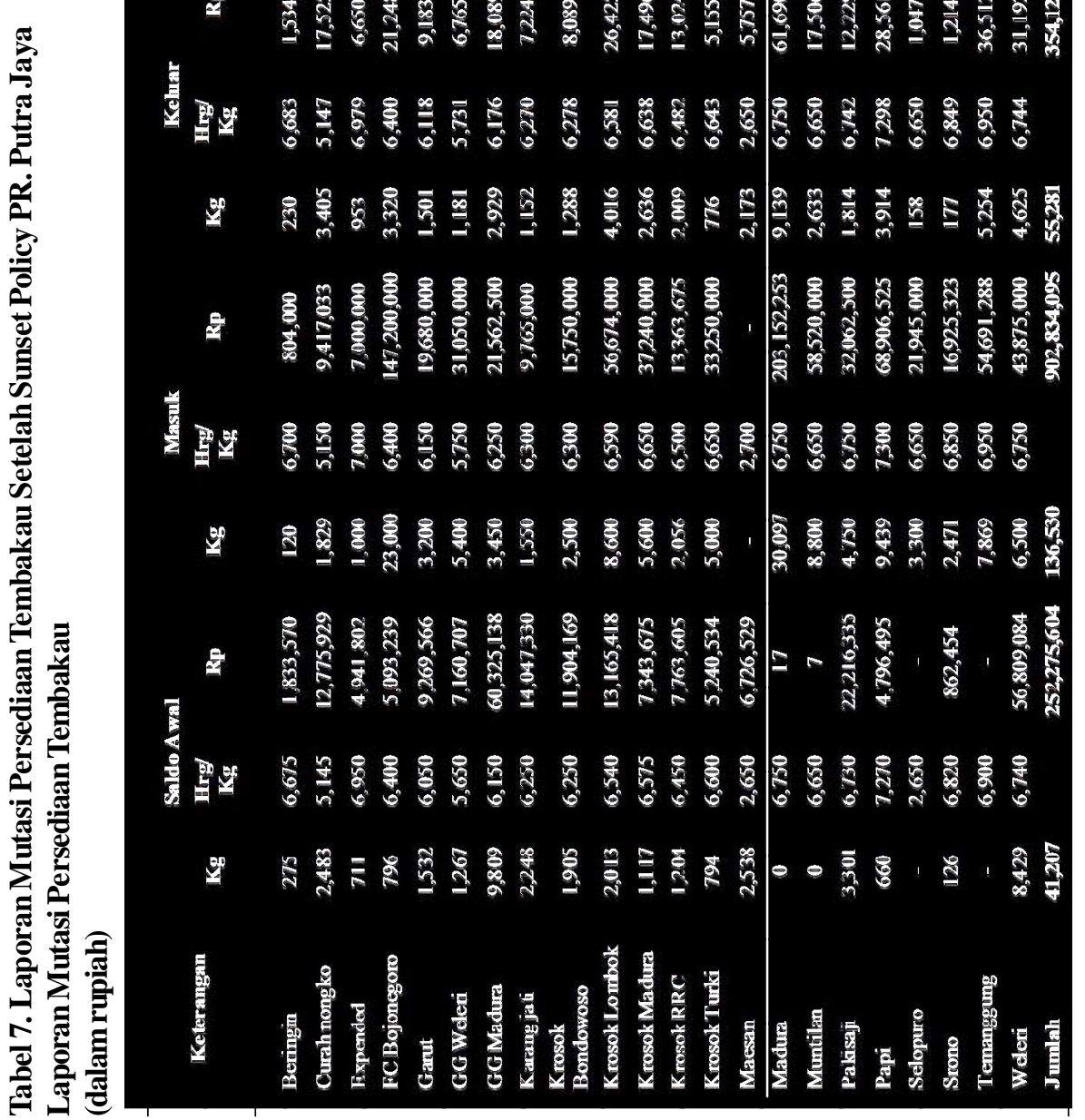

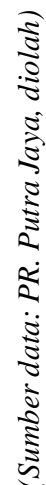


pembetulan tersebut maka besarnya beban penyusutan adalah sebesar 46.790.625, dengan nilai beban penyusutan yang meningkat tersebut maka besarnya beban usaha akan meningkat juga, beban usaha yang meningkat akan menyebabkan laba usaha juga meningkat karena diikuti penurunan beban pokok ponjualan. Apabila laba usaha meningkat maka pajak penghasilan yang harus dibayarkan juga akan meningkat.

\section{Rekonsiliasi Laporan Laba Rugi Setelah Sunset Policy}

Laporan keuangan laba rugi setelah sunset policy juga akan dilakukan rekonsiliasi. Rekonsiliasi atas laporan laba rugi akan disajikan pada tabel 8 .

Tabel 8. PR. Putra Jaya Rekonsiliasi Laporan Laba Rugi Tahun 2006 Setelah Sunset Policy

(dalam rupiah)

\begin{tabular}{|c|c|c|c|}
\hline \multirow[b]{2}{*}{ Keterangan } & \multicolumn{3}{|c|}{ Tahun 2006} \\
\hline & $\begin{array}{c}\text { Menurut } \\
\text { Komersial }\end{array}$ & $\begin{array}{c}\text { Koreksi } \\
\text { Fiskal }\end{array}$ & $\begin{array}{c}\text { Menurut } \\
\text { Fiskal }\end{array}$ \\
\hline Penjualan & $5,680,445,000$ & & $5,680,445,000$ \\
\hline Beban Pokok Penjualan & $5,351,082,412$ & & $5,351,082,412$ \\
\hline Laba Kotor & $329,362,588$ & & $329,362,588$ \\
\hline \multicolumn{4}{|l|}{ Beban Usaha } \\
\hline Beban Pemasaran & $21,288,954$ & & $21,288,954$ \\
\hline Beban Gaji Karyawan & $127,360,000$ & & $127,360,000$ \\
\hline Pemeliharaan Kendaraan & $3,225,000$ & & $3,225,000$ \\
\hline Pemeliharaan Bangunan & $3,250,000$ & & $3,250,000$ \\
\hline Beban Pemeliharaan Peralatan & $8,553,750$ & & $8,553,750$ \\
\hline Beban Listrik & $9,756,035$ & & $9,756,035$ \\
\hline Beban Telepon & $11,309,790$ & & $11,309,790$ \\
\hline Beban Transportasi & $18,000,625$ & & $18,000,625$ \\
\hline Beban Ad ministrasi & $10,835,324$ & & $10,835,324$ \\
\hline Beban Penyusutan & $46,790,625$ & & $46,790,625$ \\
\hline Sumbangan & $2,500,000$ & $(2,500,000)$ & - \\
\hline Jumlah Beban Usaha & $262,870,103$ & $(2,500,000)$ & $260,370,103$ \\
\hline Laba Rugi Usaha & $66,492,485$ & & $68,992,485$ \\
\hline Pendapatan dan Beban Lain-lain & & & - \\
\hline Pendapatan Bunga & - & & - \\
\hline Beban Lain-Lain & - & & - \\
\hline \multicolumn{4}{|l|}{ Jumlah Pendapatan, Beban Lain-lain } \\
\hline Laba Bersih Sebelum Pajak & $66,492,485$ & & $68,992,485$ \\
\hline Taksiran Pajak Penghasilan & $3,898,872$ & & \\
\hline Laba Bersih Setelah Pajak & $62,593,613$ & & \\
\hline
\end{tabular}

(Sumber data: PR. Putra Jaya, diolah) 
Pada tabel 8 rekonsiliasi laporan laba rugi tersebut terhadap akun sumbangan sebesar 2.500.000 dilakukan rekonsiliasi sehingga besarnya laba rugi usaha menurut fiskal adalah sebesar 68.992.485. Perhitungan atas taksiran pajak penghasilan pada tabel 9.

Tabel 9. Perhitungan Taksiran Pajak Penghasilan Setelah Sunset Policy PR. Putra Jaya Perhitungan Taksiran Pajak Penghasilan

(dala m rupiah)

\begin{tabular}{lr}
\hline Keterangan & Tahun 2006 \\
\hline Laba Bersih Sebelum Pajak & $68,992,485$ \\
Penghasilan Tidak Kena Pajak & $18,000,000$ \\
Penghasilan Kena Pajak & $50,992,485$
\end{tabular}

\section{Pajak Terutang}

$5 \% \times 25.000 .000=$

$1,250,000$

$10 \% \times 25.000 .000=$

2,500,000

$15 \% \times 992.480=$

148,872

Total Pajak Terutang

$\mathbf{3 , 8 9 8 , 8 7 2}$

(Sumber data: PR. Putra Jaya, diolah)

Dari tabel 9 tersebut dapat diketahui bahwa besarnya pajak terhutang pada tahun 2006 adalah sebesar 3.898.872.

\section{SIMPULAN}

Dalam penelitian ini ada beberapa hal yang dapat disimpulkan oleh penulis diantaranya adalah:

1. Dengan adanya program sunset policy yang dilakukan oleh pemerintah, maka banyak wajib pajak yang secara sukarela untuk melaporkan besarnya pajak penghasilan yang harus dibayarkan secara benar.

2. Dengan adanya sunset policy banyak wajib pajak yang merasa khawatir atas laporan keuangan yang telah dilaporkan kepada Kantor Pajak, sehingga mereka secara sadar melakukan pembetulan atas laporan yang telah dibuat sehingga mereka terbebas dari sanksi maupun denda administrasi.

Sunset policy memberikan keuntungan kepada pihak pemerintah. Yaitu dengan adanya program sunset policy maka pendapatan Negara dari sektor pajak mengalami peningkatan. 


\section{DAFTAR PUSTAKA}

Arens, Alvin, A., dan James, K.L. 1997. Auditing Pendekatan Terpadu. Ed. Indonesia Adaptasi Oleh Amir Abadi Jusuf. Ed. Revisi 1996. Cet. Kedua. Jakarta: Salemba Empat.

Baridwan, Z. 2004. Intermediate Accounting. Ed. Kedelapan. Cet. Pertama. Yogyakarta: BPFE.

Carl, S., Warren, James, M., Reeve, Phillip, E.F. 2005. Pengantar Akuntansi. Bk. Satu. Ed. Dua Puluh Satu. Jakarta: Salemba Empat.

Cooper, D.R. 1995. Metode Penelitian Bisnis. Jakarta: Erlangga.

Direktorat Jenderal Pajak. 2008. Undang-undang Republik Indonesia Nomor 28 Tahun 2007 tentang Perpajakan. Cet. Kedua. Bandung: Citra Umbara.

Endonesia. Sunset Policy untuk Tingkatkan Penerimaan Negara. Jumat, 14 Maret 2008. diakses pada Tanggal 27 Agustus 2008 dari http://www.google.com/endonesia/ BeritaHot/SunsetPolicyuntukTingkatkanPenerimaanNegara.htmhttp://www.pajak. go.id

Ikatan Akuntan Indonesia. 2007. Standar Akuntansi Keuangan per 1 September 2007. Jakarta: Salemba Empat.

Kusnadi, dkk. 2000. Pengantar Akuntansi Keuangan 1: Prinsip, Prosedur, dan Metode. Malang: Universitas Brawijaya.

Mardiasmo. 2008. Perpajakan. Ed. Revisi 2008. Yogyakarta: ANDI.

Indriantoro, N. 2002. Metode Penelitian Bisnis. Yogyakarta: BPFE.

Republik Indonesia, Departemen Keuangan. Direktorat Jenderal Pajak. 2004. Petunjuk Pengisian SPT Tahunan Pajak Penghasilan Wajib Pajak Badan. Jakarta.

Sri, V. 2003. Perpajakan Indonesia. Cet Kedua. Yogyakarta: AMPYKPN.

Waluyo. 2008. Akuntansi Pajak. Cet. Kedua. Jakarta: Salemba Empat. 